\title{
Acephate and methamidophos residues in greenhouse and in field grown tomatoes
}

\author{
Luiz Roberto P. Trevizan ${ }^{1}$; Gilberto C. de Baptista ${ }^{1}$; Geraldo Papa ${ }^{2}$ \\ ${ }^{1}$ USP/ESALQ, Depto. Entomologia, Fitopatologia e Zoologia Agrícola, C. Postal 09, 13418-900 Piracicaba-SP; ${ }^{2}$ UNESP/FEIS, Depto. \\ Fitossanidade, Engenharia Rural e Solos, Av. Brasil, 56, 15385-000 Ilha Solteira-SP;E-mail: 1rptrevi@esalq.usp.br (Autor correspondente)
}

\begin{abstract}
Increasing horticultural production under protected cultivation requires more detailed studies about the occurence of pesticide residues, due to the special and peculiar environment under controlled conditions, in which some pests, that are of little concern in the field, become important. The insecticide acephate and its methamidophos metabolite residues were evaluated in greenhouse-grown tomatoes and compared to an open-field tomato crop. The treatments: (a) check; (b) one application of $75 \mathrm{~g}$ a.i. acephate.100 $\mathrm{L}^{-1}$ water; (c) one application of $150 \mathrm{~g}$ a.i. $100 \mathrm{~L}^{-1}$ water; (d) four applications of $75 \mathrm{~g}$ a.i. $100 \mathrm{~L}^{-1}$ water were evaluated. Fruit, leaf and soil samples were taken at (-1), zero, 1, 3, 7, 14, 21 days after the last or only application. The quantitative determinations were done by gas chromatography, using flame-photometric detector. The acephate and methamidophos residues in fruits harvested in the greenhouse and in the field were always below their respective maximum residue levels (MRL) during the whole sampling period. The metabolism of acephate into methamidophos was very low in fruits, especially important in leaves, but not well characterized in soil. Acephate residues were higher in the greenhouse than in the field, especially in leaves and soil, showing stability and persistence up to the 7-day-sampling after application.
\end{abstract}

Keywords: Lycopersicon esculentum, pesticide residues, metabolism, greenhouse.

\section{RESUMO}

Resíduos de acefato e metamidofós em tomate em cultivo protegido e em campo

O aumento da produção hortícola em cultivo protegido necessita de estudos mais detalhados acerca da ocorrência de resíduos de agrotóxicos, devido às condições ambientais peculiares nesse sistema, no qual pragas de pouca importância no campo assumem relevância. Avaliou-se os resíduos dos inseticidas acefato e de seu metabólito metamidofós em tomate sob cultivo protegido e em campo. Os tratamentos aplicados foram: (a) testemunha; (b) uma aplicação de $75 \mathrm{~g}$ i.a. acefato. $100 \mathrm{~L}^{-1}$ de água; (c) uma aplicação com 150 g i.a.100 $\mathrm{L}^{-1}$ de água; (d) quatro aplicações na dosagem de $75 \mathrm{~g}$ i.a.100 $\mathrm{L}^{-1}$ de água. As amostras foram tomadas a (-1), zero, 1, 3, 7, 14 e 21 dias após a última ou única aplicação. A determinação quantitativa foi feita por técnica de cromatografia em fase gasosa, usando-se detector fotométrico de chama. Os resíduos de acefato e de metamidofós nos frutos de cultivo protegido e de campo, sempre estiveram abaixo dos respectivos limites máximos de resíduos (LMRs) em todo o período de colheita das amostras. Ainda, o metabolismo de acefato a metamidofós foi muito baixo nos frutos, particularmente importante nas folhas, mas não foi bem caracterizado no solo. Os resíduos de acefato foram maiores no cultivo protegido do que no campo, especialmente em folhas e no solo, sendo também estáveis e persistentes, em geral até a amostragem de 7 dias após a aplicação.

Palavras-chave: Lycopersicon esculentum, resíduos de pesticidas, metabolismo, cultivo protegido.

\section{(Recebido para publicação em 27 de novembro de 2003 e aceito em 29 de outubro de 2004)}

\begin{abstract}
$\mathrm{A}$ gricultural development has increased crop production under protected cultivation in recent years, attending to a market requesting differentiated and high quality products.

Protected cultivation requires the use of pesticides, but due to special and peculiar conditions found in the greenhouse environment, some pests that are of little concern in the field, become important under controlled conditions. Some insects of relevant importance under protected environment, as the whitefly, Bemisia tabaci (Genn., 1889) (HemipteraHomoptera, Aleyrodidae) and the twospotted spider mite, Tetranychus urticae (Koch, 1836) (Acari, Tetranychidae),
\end{abstract}

require the use of acephate, an organophosphorus insecticide, as well as other measures to be controlled.

Leidy et al. (1978) applied acephate under greenhouse conditions on tomato plants in unique or multiple doses. The acephate residues found in the $4^{\text {th }}$-day samples were comparable to the ones found in the $1^{\text {st }}$-day sample, indicating low dissipation. Methamidophos residues were found in all samples, even in the $1^{\text {st }}$-day, at 8 to 10 -fold lower levels than the acephate residues and were similarly persistent.

Higher residue concentrations were observed in greenhouse-grown vegetables and fruits, when compared to the cultivation in open-field, for procymidone and propargite in tomatoes (Aplada-Sarlis et al., 1994); deltamethrin, permethrin, dicofol and pyrazophos in tomatoes (Cabras et al., 1985); endosulfan in tomatoes, peppers and cucumbers (Aguilera-del Real et al., 1997); pirimicarb in peaches and nectarines (Cabras et al., 1995).

Freitas Junior \& Rigitano (1994) observed that residue levels of methamidophos in tomato decreased below the maximum residue level (MRL $=0.3 \mathrm{mg} \cdot \mathrm{kg}^{-1}$ ) after the 21-day safety interval, when the spray application was unique. However, after three sprays, the residues remained above the MRL until the end of the safety interval. The authors inferred that the "established 
safety interval is inadequate, since a weekly application of this insecticide in tomatoes is a common and regular practice that needs to be revised by competent authorities".

In this research we compared the acephate and methamidophos residues of tomato fruits and leaves and of soil from greenhouse and field cultivation; to obtain the contamination and persistence of both insecticide residues in crop/soil compartments; we also evaluated the residues in fruits from protected cultivation systems in relation to the MRL's and safety intervals established by the Brazilian legislation.

\section{MATERIAL AND METHODS}

Two experiments were carried out, one under greenhouse and another under open field conditions. The experimental design was a randomized complete block with four treatments and three replications. Blocks were separated by two double rows of border plants and the treatments within blocks by double rows of 10 plants. Each experimental unit consisted of $15 \mathrm{~m}$-double rows with plants and rows spaced $50 \mathrm{~cm}$ apart.

Acephate was used as soluble powder and the treatments were: (a) check; (b) one application of $75 \mathrm{~g}$ a.i. acephate.100 $\mathrm{L}^{-1}$ water; (c) one application of $150 \mathrm{~g}$ a.i. acephate. 100 $\mathrm{L}^{-1}$ water; (d) four applications of $75 \mathrm{~g}$ a.i. acephate. $100 \mathrm{~L}^{-1}$ water. Treatments were applied using a back-sprayer with constant 80 psi $\mathrm{CO}_{2}$-pressure and a 1.000 L.ha $^{-1}$ volume rate, enough to spray the plants to the run off point.

The samples consisted of 12 fruits and 12 composite-leaf offshoots, as much as possible randomly and representatively collected from each plot according to their spatial distribution in the plants. Twelve random soil samples were taken from underneath tomato shoots, in the area of insecticide spray dropping, using a $20 \times 20 \times 1 \mathrm{~cm}$ standard square-casting pattern.

\section{Greenhouse experiment}

The experiment was carried out in Piracicaba, São Paulo State, Brazil (22 $43^{\circ}$ ' $\mathrm{S}$ and $\left.47^{\circ} 38^{\prime} \mathrm{W}\right)$, planting the 'Carmem' $\mathrm{cv}$. in the staked tomato growing system.
In the treatment (d) (four applications of $75 \mathrm{~g}$ a.i. acephate. $100 \mathrm{~L}^{-1}$ water), applications initiated on $15^{\text {th }}$ May 2002, in the beginning of the fruit maturation period, and the subsequent applications at 7-day intervals. In the treatments (b) and (c) (one application of $75 \mathrm{~g}$ a.i. acephate. $100 \mathrm{~L}^{-1}$ water and, one application of $150 \mathrm{~g}$ a.i. acephate. $100 \mathrm{~L}^{-1}$ water, respectively) the applications were done simultaneously with the last application of the treatment (d).

Samples were taken at (-1), zero, 1 , $3,7,14$ and 21 days after the last (or unique) application, the first one on $4^{\text {th }}$ June and the last, on $26^{\text {th }}$ June 2002. A total of 252 samples of fruits, leaves and soil were collected.

\section{Field experiment}

The experiment was carried out in Pereiras, São Paulo State, Brazil ( $23^{\circ} 04^{\prime}$ $\mathrm{S}, 47^{\circ} 58^{\prime} \mathrm{W}$ ), in the staked tomato system, using the 'Santa Clara' cv.

The first application of treatment (d) was done at the beginning of the fruit maturation period, on $2^{\text {nd }}$ July 2002 and the subsequent applications at 7-day intervals. Treatments (b) and (c) were applied at the same time of the last application of treatment (d).

Samplings followed the same schedule of the greenhouse experiment, starting on $22^{\text {th }}$ July and finishing on $13^{\text {th }}$ August 2002. The local rainfall was monitored during the whole experiment.

\section{Analytical method}

The analysis method was adapted from Andersson \& Palsheden (1998), and consisted of residue extraction with ethyl acetate, residue clean-up with gel permeation chromatography (GPC) technique and quantitative determination by gas chromatography using a Varian chromatograph, Star 3400 $\mathrm{Cx}$ model, equipped with pulsing flame photometric detector (PFPD), $526 \mathrm{~nm}$ phosphorus specific filter, automatic injector, BPX-35 megabore chromatographic column (30 m length; $0.53 \mathrm{~mm}$ internal diameter; $1.0 \mu \mathrm{m}$ film thickness) and Varian workstation Star model, 5.51 version software.

For the fruit and leaf analysis, $10 \mathrm{~g}$ of homogenized samples were transferred to a $100 \mathrm{ml}$ Duran-Schott flask, to which $50 \mathrm{ml}$ ethyl acetate and
$10 \mathrm{~g} \mathrm{Na}_{2} \mathrm{SO}_{4}$ were added. After that, the preparations were homogenized in an Ultra-Turrax device, during 2 minutes at 26,000 rpm and centrifuged during 5 minutes at 2,500 rpm. Ten $\mathrm{ml}$ supernatant aliquot samples were transferred to $50 \mathrm{ml}$ polypropylene tube and evaporated to dryness in water-bath at $40^{\circ} \mathrm{C}$ constant temperature under airflow, previously dried through silica gel filters.

For soil analysis, $20 \mathrm{~g}$ air-dried soil sample was transferred to extraction cell compartment of the accelerated solvent extractor equipment (Dionex, Ase 300 model) and extracted with ethyl acetate. The equipment was operated at $100^{\circ} \mathrm{C}$ and 1,500 psi positive pressure during 15 minutes, after which approximately $120 \mathrm{ml}$ extract was collected in Dionex vial. The extract was taken to a Turbovap evaporator until complete drying under a slight $\mathrm{N}_{2}$ flow at $40^{\circ} \mathrm{C}$.

The sample extracts (fruit, leaf and soil) were cleaned up through gel permeation chromatography (GPC). The residues of the two insecticides were resuspended in $2 \mathrm{ml}$ ethyl acetate/ cyclohexane $(1 / 1, \mathrm{v} / \mathrm{v})$ mixture, by rinsing the polypropylene tubes and collecting the extracts in $15 \mathrm{ml}$ centrifuge tubes, which were taken to a mini-shaker for 1 minute and later submitted to ultrasound for another minute. After that, the extracts were filtered through a $0.20 \mu$ mesh Millipore membrane, transferred to vials and then injected into the GPC system (operated with a $1 \mathrm{ml} \cdot \mathrm{min}^{-1}$ ethyl acetate/cyclohexane flow). The eluates were discarded during the first 22 minutes and collected during the subsequent 5 minutes in $15 \mathrm{ml}$ centrifuge tubes, which were taken to a TurboVap LV evaporator until complete extract drying under a slight $\mathrm{N}_{2}$ flow at $40^{\circ} \mathrm{C}$.

The residues were re-suspended in exactly $1 \mathrm{ml}$ acetone, transferred to autosampler vials and injected into the gas chromatograph system, mode splitless, with a linear sloping temperature program (injector temperature $=220^{\circ} \mathrm{C}$; column temperatures $=120^{\circ} \mathrm{C}$ for 7 minutes (start) to, $280^{\circ} \mathrm{C}$ for 4 minutes, ramp $27.5^{\circ} \mathrm{C} \cdot \mathrm{min}^{-1}$; detector temperature $=300^{\circ} \mathrm{C}$ ). The gas flows were: $\mathrm{He}=5$ $\mathrm{ml} \cdot \mathrm{min}^{-1}$, air $=27 \mathrm{ml} \cdot \mathrm{min}^{-1}$ and $\mathrm{H}_{2}=14$ ml. $\min ^{-1}$. 
Table 1. Acephate and methamidophos residues in tomato fruit of greenhouse and field crops. Piracicaba, ESALQ, 2002.

\begin{tabular}{|c|c|c|c|c|c|}
\hline \multirow{3}{*}{ Treatment } & \multirow{3}{*}{$\begin{array}{l}\text { Days after } \\
\text { application }\end{array}$} & \multicolumn{4}{|c|}{ Residues in fruits $\left(\mathrm{mg} \cdot \mathrm{kg}^{-1}\right)^{*}$} \\
\hline & & \multicolumn{2}{|c|}{ greenhouse } & \multicolumn{2}{|c|}{ field } \\
\hline & & acephate & methamidophos & acephate & methamidophos \\
\hline \multirow{7}{*}{ check } & -1 & $<0.05$ & $<0.05$ & $<0.05$ & $<0.05$ \\
\hline & 0 & $<0.05$ & $<0.05$ & $<0.05$ & $<0.05$ \\
\hline & 1 & $<0.05$ & $<0.05$ & $<0.05$ & $<0.05$ \\
\hline & 3 & $<0.05$ & $<0.05$ & $<0.05$ & $<0.05$ \\
\hline & 7 & $<0.05$ & $<0.05$ & $<0.05$ & $<0.05$ \\
\hline & 14 & $<0.05$ & $<0.05$ & $<0.05$ & $<0.05$ \\
\hline & 21 & $<0.05$ & $<0.05$ & $<0.05$ & $<0.05$ \\
\hline \multirow{7}{*}{$\begin{array}{l}75 \mathrm{~g} \text { a.i.100 L-1 } \\
\text { of water } \\
\text { (1 application) }\end{array}$} & -1 & $<0.05$ & $<0.05$ & $<0.05$ & $<0.05$ \\
\hline & 0 & $0.13 \pm 0.02$ & $<0.05$ & $0.12 \pm 0.03$ & $<0.05$ \\
\hline & 1 & $0.1 \pm 0.02$ & $<0.05$ & $0.10 \pm 0.03$ & $<0.05$ \\
\hline & 3 & 0.05 & $<0.05$ & $0.11 \pm 0.01$ & $<0.05$ \\
\hline & 7 & $0.33 \pm 0.08$ & $<0.05$ & $0.30 \pm 0.09$ & $<0.05$ \\
\hline & 14 & $0.08 \pm 0.01$ & $<0.05$ & $0.13 \pm 0.01$ & $<0.05$ \\
\hline & 21 & $<0.05$ & $<0.05$ & $<0.05$ & $<0.05$ \\
\hline \multirow{7}{*}{$\begin{array}{l}150 \mathrm{~g} \text { a.i. } 100 \mathrm{~L}-1 \\
\text { of water } \\
\text { (1 application) }\end{array}$} & -1 & $<0.05$ & $<0.05$ & $<0.05$ & $<0.05$ \\
\hline & 0 & $0.20 \pm 0.04$ & $<0.05$ & $0.30 \pm 0.06$ & $<0.05$ \\
\hline & 1 & 0.13 & $<0.05$ & $0.10 \pm 0.02$ & $<0.05$ \\
\hline & 3 & $0.15 \pm 0.03$ & $<0.05$ & $0.13 \pm 0.03$ & $<0.05$ \\
\hline & 7 & $0.26 \pm 0.04$ & $<0.05$ & $0.30 \pm 0.04$ & $<0.05$ \\
\hline & 14 & $0.12 \pm 0.02$ & $<0.05$ & $0.20 \pm 0.02$ & $<0.05$ \\
\hline & 21 & $<0.05$ & $<0.05$ & $0.07 \pm 0.02$ & $<0.05$ \\
\hline \multirow{7}{*}{$\begin{array}{l}75 \mathrm{~g} \text { a.i. } 100 \mathrm{~L}-1 \\
\text { of water } \\
\text { (4 applications) }\end{array}$} & -1 & $0.17 \pm 0.01$ & $<0.05$ & $<0.05$ & $<0.05$ \\
\hline & 0 & $0.31 \pm 0.10$ & 0.09 & $0.27 \pm 0.06$ & $<0.05$ \\
\hline & 1 & $0.37 \pm 0.07$ & $0.09 \pm 0.01$ & $0.20 \pm 0.05$ & $<0.05$ \\
\hline & 3 & $0.24 \pm 0.07$ & $0.09 \pm 0.01$ & $0.23 \pm 0.02$ & $0.11 \pm 0.02$ \\
\hline & 7 & $0.41 \pm 0.01$ & $0.11 \pm 0.01$ & $0.40 \pm 0.01$ & $<0.05$ \\
\hline & 14 & $0.09 \pm 0.02$ & $0.12 \pm 0.03$ & $0.30 \pm 0.08$ & $<0.05$ \\
\hline & 21 & $<0.05$ & 0.12 & $0.17 \pm 0.04$ & $<0.05$ \\
\hline
\end{tabular}

* average value of three replications

Under these conditions, the retention times for methamidophos was 4 minutes and 30 seconds and for acephate was 5 minutes and 30 seconds. The residues were calculated directly from the correspondent calibration curves for acephate $\quad\left(\mathrm{r}^{2}=0.9964\right) \quad$ and methamidophos $\left(\mathrm{r}^{2}=0.9937\right)$, previously plotted by comparison with standards.

\section{Analytical method validation}

The analytical method validation was confirmed with fortification and recovery studies for acephate and methamidophos. For that, fruit and soil samples were fortified to obtain concentrations of $10 ; 5$; $1 ; 0.5 ; 0.1 ; 0.05$ and $0.01 \mathrm{mg} . \mathrm{kg}^{-1}$; and leaf samples, of $100 ; 50 ; 10 ; 5 ; 1 ; 0.5$ and 0.1 $\mathrm{mg} . \mathrm{kg}^{-1}$, for both insecticides, with triplicate determinations. In this way, based on these recovery studies, the limits of quantitation (LOQ's) were $0.05 \mathrm{mg} . \mathrm{kg}^{-1}$ for the fruit and soil samples, and 0.5 mg. $\mathrm{kg}^{-1}$ for the leaf, for both analytes. The recoveries in fruits were: acephate 83$117 \%$, methamidophos $83-111 \%$; in leaves were: acephate $74-117 \%$, methamidophos $77-109 \%$ and, in soil were: acephate $73-116 \%$, methamidophos $79-117 \%$. The recovery determinations were considered satisfactory and gave support to validate the method, when they were between 70 and $120 \%$.

\section{RESULTS AND DISCUSSION}

\section{Residues in fruits}

Acephate residues in tomato fruits, from both greenhouse and open field,
(Table 1) were always below the maximum residue limit (MLR $=0.5$ $\left.\mathrm{mg} \cdot \mathrm{kg}^{-1}\right)$ at any dosage or sampling date (Agência Nacional de Vigilância Sanitária, 2003a). Concerning the unique applications of 75 or $150 \mathrm{~g}$ a.i 100 $\mathrm{L}^{-1}$, an almost 2-fold dissipation degree was observed in the greenhouse in the 14day sampling (0.13-0.08 and 0.20-0.12 mg.kg ${ }^{-1}$, respectively). In relation to the four application-treatments, an overlapping effect of the sprayings was observed $\left(0.17 \mathrm{mg} \cdot \mathrm{kg}^{-1}\right.$ in the -1 -day sampling), with similar contamination increase $\left(0.14 \mathrm{mg} . \mathrm{kg}^{-1}\right)$ compared to the one observed in the equivalent uniqueapplication $\left(0.13 \mathrm{mg} \cdot \mathrm{kg}^{-1}\right)$ in the zero-day sampling, however, with a faster insecticide dissipation (0.31-0.09 mg.kg-1). 
Acephate and methamidophos residues in greenhouse and in field grown tomatoes

Table 2. Acephate and methamidophos residues in tomato leaf of greenhouse and field crops. Piracicaba, ESALQ, 2002.

\begin{tabular}{|c|c|c|c|c|c|}
\hline \multirow{3}{*}{ Treatment } & \multirow{3}{*}{$\begin{array}{l}\text { Days after } \\
\text { application }\end{array}$} & \multicolumn{4}{|c|}{ Residues in leaves $\left(\mathrm{mg} \cdot \mathrm{kg}^{-1}\right)^{*}$} \\
\hline & & \multicolumn{2}{|c|}{ greenhouse } & \multicolumn{2}{|c|}{ field } \\
\hline & & acephate & methamidophos & acephate & methamidophos \\
\hline \multirow{7}{*}{ check } & -1 & $<0.5$ & $<0.5$ & $<0.5$ & $<0.5$ \\
\hline & 0 & $<0.5$ & $<0.5$ & $<0.5$ & $<0.5$ \\
\hline & 1 & $<0.5$ & $<0.5$ & $<0.5$ & $<0.5$ \\
\hline & 3 & $<0.5$ & $<0.5$ & $<0.5$ & $<0.5$ \\
\hline & 7 & $<0.5$ & $<0.5$ & $<0.5$ & $<0.5$ \\
\hline & 14 & $<0.5$ & $<0.5$ & $<0.5$ & $<0.5$ \\
\hline & 21 & $<0.5$ & $<0.5$ & $<0.5$ & $<0.5$ \\
\hline \multirow{7}{*}{$\begin{array}{l}75 \mathrm{~g} \text { a.i.100 } \mathrm{L}^{-1} \\
\text { of water } \\
\text { (1 application) }\end{array}$} & -1 & $<0.5$ & $<0.5$ & $<0.5$ & $<0.5$ \\
\hline & 0 & $37.6 \pm 2.7$ & 0.5 & $14.0 \pm 3.5$ & $0.62 \pm 0.20$ \\
\hline & 1 & $27.5 \pm 7.6$ & $0.77 \pm 0.14$ & $11.0 \pm 1.8$ & $0.69 \pm 0.01$ \\
\hline & 3 & $15.3 \pm 1.3$ & $1.17 \pm 0.29$ & $6.4 \pm 1.0$ & $0.54 \pm 0.10$ \\
\hline & 7 & $19.5 \pm 5.1$ & $1.4 \pm 0.23$ & $3.8 \pm 0.52$ & $0.70 \pm 0.08$ \\
\hline & 14 & $14.3 \pm 2.6$ & $1.04 \pm 0.21$ & $0.91 \pm 0.08$ & $1.0 \pm 0.03$ \\
\hline & 21 & $12.1 \pm 3.4$ & $1.6 \pm 0.23$ & $1.1 \pm 0.30$ & $<0.5$ \\
\hline \multirow{7}{*}{$\begin{array}{l}150 \mathrm{~g} \text { a.i. } 100 \mathrm{~L}^{-1} \\
\text { of water } \\
\text { (1 application) }\end{array}$} & -1 & $<0.5$ & $<0.5$ & $<0.5$ & $<0.5$ \\
\hline & 0 & $51.4 \pm 9.7$ & $0.8 \pm 0.2$ & $24.0 \pm 5.3$ & $1.2 \pm 0.23$ \\
\hline & 1 & $38.6 \pm 5.8$ & $0.97 \pm 0.11$ & $24.0 \pm 2.8$ & $1.3 \pm 0.13$ \\
\hline & 3 & $26.7 \pm 3.7$ & $1.97 \pm 0.23$ & $12.0 \pm 0.83$ & $0.9 \pm 0.14$ \\
\hline & 7 & $38.0 \pm 10.4$ & $2.6 \pm 0.34$ & $10.0 \pm 1.1$ & $1.1 \pm 0.11$ \\
\hline & 14 & $26.6 \pm 3.7$ & $2.4 \pm 0.2$ & $1.9 \pm 0.06$ & $1.2 \pm 0.03$ \\
\hline & 21 & $17.9 \pm 1.7$ & $2.3 \pm 0.15$ & $2.1 \pm 0.50$ & $0.3 \pm 0.04$ \\
\hline \multirow{7}{*}{$\begin{array}{l}75 \mathrm{~g} \text { a.i.100 } \mathrm{L}^{-1} \\
\text { of water } \\
\text { (4 applications) }\end{array}$} & -1 & $34.6 \pm 6.3$ & $2.5 \pm 0.2$ & $22.0 \pm 6.2$ & $2.7 \pm 0.89$ \\
\hline & 0 & $53.7 \pm 7.0$ & $3.2 \pm 0.8$ & $28.0 \pm 6.5$ & $2.5 \pm 0.42$ \\
\hline & 1 & $65.1 \pm 8.2$ & $4.2 \pm 0.75$ & $40.0 \pm 11.0$ & $4.0 \pm 0.87$ \\
\hline & 3 & $40.0 \pm 5.3$ & $4.4 \pm 0.5$ & $23.0 \pm 5.1$ & $2.5 \pm 0.53$ \\
\hline & 7 & $42.3 \pm 5.8$ & $4.9 \pm 0.35$ & $14.0 \pm 2.5$ & $1.7 \pm 0.21$ \\
\hline & 14 & $27.7 \pm 4.5$ & $3.1 \pm 0.40$ & $4.3 \pm 1.0$ & $1.5 \pm 0.17$ \\
\hline & 21 & $17.6 \pm 3.4$ & $3.8 \pm 1.18$ & $6.0 \pm 1.3$ & $0.9 \pm 0.10$ \\
\hline
\end{tabular}

* average value of three replications.

Fruits from open-field presented persistent acephate residues until 14-day sampling, decreasing rapidly after this date. The residue values observed in the greenhouse and field were generally similar within the same treatments (Table 1), although higher residue concentrations were expected in the greenhouse. This might be explained because of the larger fruit volume/area ratio presented by the 'Carmem' cv planted in the greenhouse, compared to the 'Santa Clara', resulting in a residue "dilution". The higher residue values observed in the 7-day samples, might be attributed to the fact that the collected fruits were located on the top of the plants when compared to the earlier samplings, and therefore more exposed to the acephate. Besides, the fruits from the upper part of the plant were smaller with greater specific surface area in proportion to volume, what might result in higher residue levels.

The acephate metabolism was not intense in the greenhouse and methamidophos metabolite was only found in the four-application treatments (Table 1), in the 1-day samples after the last application, whose concentration remained constant until the last sampling (0.09-0.12 mg. $\left.\mathrm{kg}^{-1}\right)$. Such results were similar to those obtained from Leidy et al. (1978).

Methamidophos residues, always below the MRL $\left(0.5 \mathrm{mg} \cdot \mathrm{kg}^{-1}\right)$, were found in few greenhouse or field fruit samples, including the 21-day safety interval according to the Agência Nacional de Vigilância Sanitária (2003b). Similar methamidophos values were found in both environments, indicating again a low metabolism rate and possibly that the metabolite may be quickly dissipated as soon as formed.

\section{Residues in the leaves}

Acephate residues in the leaves collected from the greenhouse, similar to the values found on the fruits, showed certain stability among the treatments until the 7-day sampling (Table 2) with average values ranging from 38 to 54 mg.kg-1 (zero-day samples) and 20 to 42 mg. $\mathrm{kg}^{-1}$ (7-day samples), after which they decreased rapidly. Lower values were found in the leaves from the field experiment, indicating residue 
Table 3. Acephate and methamidophos residues in greenhouse and field soils cultivated with tomato crops. Piracicaba, ESALQ, 2002.

\begin{tabular}{|c|c|c|c|c|c|}
\hline \multirow{3}{*}{ Treatment } & \multirow{3}{*}{$\begin{array}{l}\text { Days after } \\
\text { application }\end{array}$} & \multicolumn{4}{|c|}{ Residues in soils $\left(\mathrm{mg} \cdot \mathrm{kg}^{-1}\right)^{*}$} \\
\hline & & \multicolumn{2}{|c|}{ greenhouse } & \multicolumn{2}{|c|}{ field } \\
\hline & & acephate & methamidophos & acephate & methamidophos \\
\hline \multirow{7}{*}{ check } & -1 & $<0.05$ & $<0.05$ & $<0.05$ & $<0.05$ \\
\hline & 0 & $<0.05$ & $<0.05$ & $<0.05$ & $<0.05$ \\
\hline & 1 & $<0.05$ & $<0.05$ & $<0.05$ & $<0.05$ \\
\hline & 3 & $<0.05$ & $<0.05$ & $<0.05$ & $<0.05$ \\
\hline & 7 & $<0.05$ & $<0.05$ & $<0.05$ & $<0.05$ \\
\hline & 14 & $<0.05$ & $<0.05$ & $<0.05$ & $<0.05$ \\
\hline & 21 & $<0.05$ & $<0.05$ & $<0.05$ & $<0.05$ \\
\hline \multirow{7}{*}{$\begin{array}{l}75 \mathrm{~g} \text { a.i. } 100 \mathrm{~L}^{-1} \\
\text { of water } \\
\text { (1 application) }\end{array}$} & -1 & $<0.05$ & $<0.05$ & $<0.05$ & $<0.05$ \\
\hline & 0 & $0.23 \pm 0.04$ & $<0.05$ & $0.13 \pm 0.04$ & $<0.05$ \\
\hline & 1 & $1.4 \pm 0.4$ & $<0.05$ & $0.25 \pm 0.05$ & $<0.05$ \\
\hline & 3 & $1.8 \pm 0.35$ & $<0.05$ & $<0.05$ & $<0.05$ \\
\hline & 7 & $1.4 \pm 0.44$ & $<0.05$ & $0.31 \pm 0.05$ & $<0.05$ \\
\hline & 14 & $0.39 \pm 0.09$ & $<0.05$ & $<0.05$ & $<0.05$ \\
\hline & 21 & $0.84 \pm 0.21$ & $<0.05$ & $<0.05$ & $<0.05$ \\
\hline \multirow{7}{*}{$\begin{array}{l}150 \mathrm{~g} \text { a.i. } 100 \mathrm{~L}^{-1} \\
\text { of water } \\
\text { (1 application) }\end{array}$} & -1 & $<0.05$ & $<0.05$ & $<0.05$ & $<0.05$ \\
\hline & 0 & $0.77 \pm 0.05$ & $<0.05$ & $0.18 \pm 0.04$ & $<0.05$ \\
\hline & 1 & $2.5 \pm 0.4$ & $<0.05$ & $0.19 \pm 0.05$ & $<0.05$ \\
\hline & 3 & $4.0 \pm 0.62$ & $<0.05$ & $0.11 \pm 0.02$ & $<0.05$ \\
\hline & 7 & $3.0 \pm 0.08$ & $<0.05$ & $0.63 \pm 0.24$ & $<0.05$ \\
\hline & 14 & $1.7 \pm 0.05$ & $<0.05$ & $<0.05$ & $<0.05$ \\
\hline & 21 & $3.3 \pm 0.04$ & $<0.05$ & $<0.05$ & $<0.05$ \\
\hline \multirow{7}{*}{$\begin{array}{l}75 \mathrm{~g} \text { a.i.100 } \mathrm{L}^{-1} \\
\text { of water } \\
\text { ( } 4 \text { applications) }\end{array}$} & -1 & $0.28 \pm 0.08$ & $<0.05$ & $0.16 \pm 0.05$ & $<0.05$ \\
\hline & 0 & $1.0 \pm 0.24$ & $<0.05$ & $0.24 \pm 0.07$ & $<0.05$ \\
\hline & 1 & $3.1 \pm 0.5$ & $<0.05$ & $0.23 \pm 0.05$ & $<0.05$ \\
\hline & 3 & $3.7 \pm 0.96$ & $<0.05$ & $0.18 \pm 0.06$ & $<0.05$ \\
\hline & 7 & $2.3 \pm 0.06$ & $<0.05$ & $0.53 \pm 0.12$ & $<0.05$ \\
\hline & 14 & $1.8 \pm 0.05$ & $<0.05$ & $<0.05$ & $<0.05$ \\
\hline & 21 & $4.0 \pm 1.3$ & $<0.05$ & $<0.05$ & $<0.05$ \\
\hline
\end{tabular}

*average of three replications.

degradation mainly after the 3 -day sampling and a possible influence of climate conditions. In both experiments, the acephate residues were 10 to 40 -fold higher in the leaves than fruits, because the leaves were much more exposed to spraying and present a very higher specific surface area compared to the fruits.

Leaf methamidophos residue concentrations from both experiments were also much higher than in fruits and were found in every insecticide sprayed sample, during the whole sampling period (Table 2, Figure 1). Such results can be explained by the higher leaf acephate residues and leaf acephate metabolism, with maximum values at the 7-day sampling, remaining constant until the end of the greenhouse experiment or decreasing 2-fold in the field experiment. In the field, the produced methamidophos was rapidly degraded, but persisted longer in the greenhouse, especially in the four-application treatment, when an accumulation was observed. This might indicate a potential hazard to the workers, because methamidophos is much more toxic than acephate (acute dermal toxicity for rats: methamidophos, $\mathrm{DL}_{50}=130$ mg. $\mathrm{kg}^{-1}$; acephate, $\mathrm{DL}_{50}>2.000 \mathrm{mg} . \mathrm{kg}^{-1}$; Tomlin, 1995).

\section{Residues in the soil}

Under greenhouse conditions, the acephate residue concentrations of the soil were between fruit and leaf values (about 2 to 8 times that of the fruit) and were almost always higher in the 3 -day samples, after that remaining constant. No methamidophos residues were found in all soil samples from the greenhouse or field $\left(<0.05 \mathrm{mg} \cdot \mathrm{kg}^{-1}\right)$ (Table 3), indicating that acephate residues were not metabolized or were rapidly dissipated or transported, dissolved and percolated into the soil profile.

Residue run off from the shoots to the soil during the 24-hour period subsequent to the sprayings caused a 3 to 7-fold higher acephate concentration in the zero and 1-day samplings, probably due to capillary transport in the soil solution (high water solubility - 700 g. $\mathrm{L}^{-1}$ at $20^{\circ} \mathrm{C}$; Tomlin, 1995). Besides, the acephate soil contamination was higher in the protected cultivation than in the open-field. Field residue concentration 


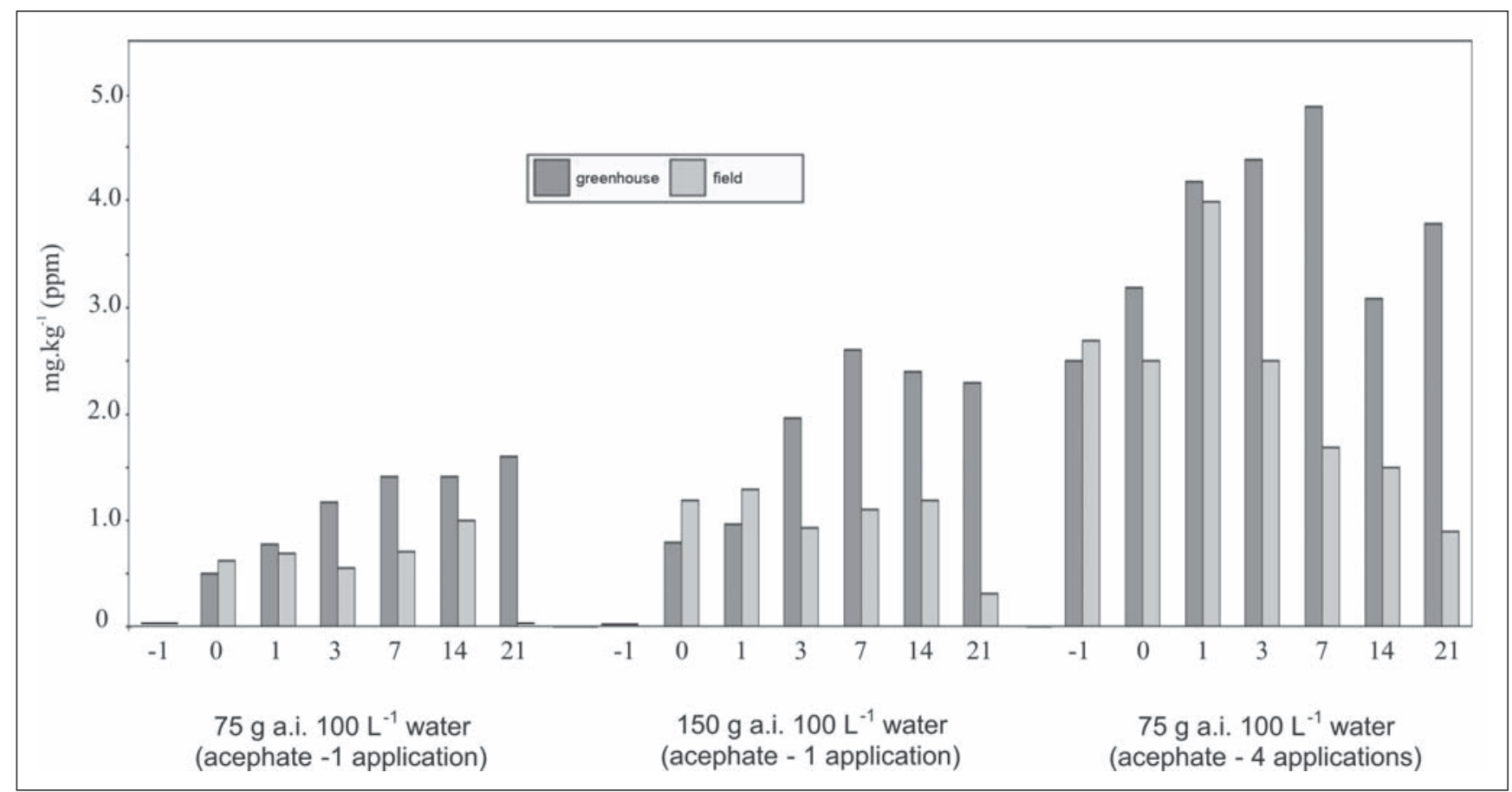

Figure 1. Metamidophos residues in tomato leaves under greenhouse and field cultivation. Piracicaba, ESALQ, 2002.

decreased very rapidly after the 7-day sampling; and after the 14-day reached values below the Loq $\left(<0.05 \mathrm{mg} \cdot \mathrm{kg}^{-1}\right)$, which might be attributed to the heavy rainfall $(63 \mathrm{~mm})$ observed between the 7- and 14-day samplings.

In all circumstances, the residue concentration values from the check samples, for the two analytes and the three substrates, were always below the respective Loq's, evidencing no crossed contamination between the plots from the respective spraying applications.

The acephate and methamidophos residues were, in general, higher in the protected cultivation conditions, in the leaves and soil, than in the open-field, which is in agreement with Cabras et al. (1985), Frank et al. (1987), Von Stryk \& Jarvis (1978), Meloni et al. (1984) and cabras et al. (1995). These authors, working with several pesticides and different substracts, have also observed higher residue levels in samples from protected cultivation than from the openfield.

\section{ACKNOWLEDGEMENTS}

To the 'Fundação de Amparo à Pesquisa do Estado de São Paulo' for the financial support and to Hokko do Brasil, Industria Química e Agropecuária Ltda. for the technical support during the research work.

\section{CITED LITERATURE}

AGÊNCIA NACIONAL DE VIGILÂNCIA SANITÁRIA. Toxicologia: monografia dos produtos agrotóxicos. acefato. Avaible: <http:// www.anvisa4.anvisa.gov.br/AGROSIA/asp/ frm_dados ingrediente.asp $=7>$. Accessed on $11^{\text {th }}$ set. 2003a.

AGÊNCIA NACIONAL DE VIGILÂNCIA SANITÁRIA. Toxicologia: monografia dos produtos agrotóxicos. metamidofós. Avaible on: $<\mathrm{http}$ :/ /www.anvisa4.anvisa.gov.br/AGROSIA/asp/ frm_dados_ingrediente.asp $=269>$. Accessed on $11^{\text {th }}$ set. $2003 \mathrm{~b}$.

AGUILERA-del REAL, A.; VALVERDEGARCIA, A.; FERNANDEZ-ALBA, A. R.; CAMACHO-FERRE, F. Behaviour of endosulfan residues in peppers, cucumbers and cherry tomatoes grown in greenhouse: evaluation of decline curves. Pesticide Science, v.51, p.194-200, 1997.

ANDERSSON, A.; PALSHEDEN, H. Multiresidue method for the analysis of pesticides in fruit and vegetables using ethyl acetate extraction, GPC clean-up and GC determination. In: NATIONAL FOOD ADMINISTRATION. Pesticide analytical methods in Sweden, 1998. pt.1, p.9-41. (Rapport, 17/18).

APLADA-SARLIS, P.; LIAPIS, K.S.; MILIADIS, G.E. Study of procymidone and propargite residue levels resulting from application to greenhouse tomatoes. Journal of Agricultural and Food Chemistry, v.42, p.1575-1577, 1994.
CABRAS, P.; CABITZA, F.; MELONI, M.; PIRISI, F.M. Behavior of some pesticide residues on greenhouse tomatoes. 2. fungicides, acaricides, and insecticides. Journal of Agricultural and Food Chemistry, v.33, p.935-937, 1985.

CABRAS, P.; MELIS, M.; CABITZA, F.; CUBEDDU, M.; SPANEDDA, L. Persistence of pirimicarb in peaches and nectarines. Journal of Agricultural and Food Chemistry, v.43, p.22792282, 1995.

FRANK, R.; BRAUN, H.E.; RITCEY, G. Disappearance of captan from field and greenhouse-grown tomato fruit in relationship to time of harvest and amount of rainfall. Canadian Journal of Plant Science, v.67, p.355-357, 1987. FREITAS JUNIOR, J.R.; RIGITANO, R.L.O. Dissipação dos resíduos do inseticida metamidofós em frutos de tomateiro (Lycopersicon esculentum Mill). Ciência e Prática, v.18, p.37-41, 1994.

LEIDY, R.B.; SHEETS, T.J.; SORENSEN, K.A. Residues of acephate and methamidophos in greenhouse tomatoes. Journal of the American Society of Horticultural Science, v.103, p.392-394, 1978.

MELONI, M.; PIRISI, F.M..; CABRAS, P.; CABITZA, F. Residues of fungicides on greenhouse lettuce. Journal of Agricultural and Food Chemistry, v.32, p.183-185, 1984.

TOMLIN, C. The pesticide manual. 10. ed. Cambridge: The Royal Society of Chemistry, 1995. $1341 \mathrm{p}$.

VON STRYK, F.G.; JARVIS, W.R. Residues of mancozeb, maneb and ethylenethiourea in fungicide-treated field and greenhouse tomatoes. Canadian Journal of Plant Science, v.58, p.623628, 1978. 